\title{
Investigating the Perception of Stakeholders on Soft Skills Development of Students: Evidence from South Africa
}

\author{
Estelle Taylor \\ Potchefstroom Campus, North-West University, \\ Potchefstroom, South Africa
}

\section{estelle.taylor@nwu.ac.za}

\begin{abstract}
Soft skills are becoming increasingly important and will be critical for success in the Information Systems profession. Employers complain about a lack in soft skills among graduates from tertiary education institutions. No agreement exists about what these skills actually are, which are of importance, and how acquiring these soft skills should be approached in higher education.

The aim of this paper is to research the perceptions of lecturers, industry, and students on soft skills development of students and to identify important soft skills that need to be developed. The paper starts with a problem statement emphasizing the importance of soft skills and the possible lack thereof. This is followed by a literature review, a description of the methodology followed for this research, the results, conclusion, and the references.

The research was done at a university in South Africa. Questionnaires consisting of open questions were distributed to lecturers, industry, and students respectively, and qualitative analysis was done on the results.

Results show that stakeholders feel that soft skills of students are not developed adequately, that there is some uncertainty about who should be responsible for developing soft skills, and that the development of soft skills is seen as a difficult task. A list is compiled of the most important soft skills according to literature, lecturers, industry, and students. This list can be used in further research on the soft skills of IT-students. Recommendations are made for the teaching and learning of soft skills.
\end{abstract}

Keywords: soft skills, higher education, information technology, industry

\section{Introduction}

Material published as part of this publication, either on-line or in print, is copyrighted by the Informing Science Institute. Permission to make digital or paper copy of part or all of these works for personal or classroom use is granted without fee provided that the copies are not made or distributed for profit or commercial advantage AND that copies 1) bear this notice in full and 2) give the full citation on the first page. It is permissible to abstract these works so long as credit is given. To copy in all other cases or to republish or to post on a server or to redistribute to lists requires specific permission and payment of a fee. Contact Publisher@InformingScience.org to request redistribution permission.
Joseph, Ang, Chang, and Slaughter (2010) refer to a growing awareness that technical skills alone are insufficient for success in IT, particularly in today's dynamic, distributed, and complex workplace. A broader set of skills, beyond traditional technical skills, are required, and these are labelled soft skills. Employers complain about a lack in soft skills among graduates from tertiary education institutions (Schulz, 2008). The situa- 
tion is further complicated because no agreement exists about what these skills actually are, which are of importance and how acquiring them should be approached in higher education (Adomssent et al., 2007). For many years industry recruiters have been emphasizing the importance of soft kills, e.g., interpersonal communication skills and teamwork (Russell, Russell, \& Tastle, 2005). The possession of soft skills is strongly associated with life and employment success (Gibb, 2014) and the realisation of importance of soft skills is on the increase (Azim et al., 2010).

According to Bancino and Zevalkink (2007) the increased demand for a broader skill set is because of the necessity for improvements to the bottom line, increasing competition, and globalization. Business executives consider soft skills a very important attribute in job applicants because soft skills are seen as critical for productive performance (Robles, 2012).

It is not enough to be academically strong; employees need to work with other cultures, communicate well, and be punctual and dependable (Gewertz, 2007). Soft skills are becoming increasingly important, and soft skills such as teamwork and collaboration, planning and leading projects, presentation delivery, and writing skills will be critical for success in the Information Systems profession (Noll \& Wilkins, 2002).

The aim of this paper is to research the perceptions of lecturers, industry, and students on soft skills, and to identify important soft skills that need to be developed. The paper starts with a problem statement emphasizing the importance of soft skills and the possible lack thereof. In the literature review the terminology is defined, and a list of important soft skills is compiled. This is followed by a description of the methodology followed for this research, the results, conclusion and the references.

\section{Problem Statement}

Bancino and Zevalkink (2007) wrote that the focus of education and training is on technical topics and mathematics, science, and technical skills, yet the fast-paced, global marketplace of today is demanding more. Technical professionals in disciplines such as information technology, engineering, architecture, and research and development are increasingly required to broaden their skill sets to master the so-called soft skills.

The skills gap that has employers worried isn't the technical skills gap, but the soft skills gap. Senior management complain about the lack of soft skills in new employees and emphasize that knowledge alone is not enough to succeed, but that effective communication also influences success (Klaus, 2010). The practical importance of soft skills has been amply illustrated through research attempting to define factors related to project and project management success (Stevenson \& Starkweather, 2010).

Technical skills are a part of most educational curricula, but soft skills need further emphasis in the university curricula (Robles, 2012). Douglas (2002) argues, "...it is an accepted truism that some people who are gifted from a scientific and technical point of view find their career progress checked by their fundamental difficulties with managing people. They cannot be blamed for their lack of facility in this area, their entire training has been based around acquiring the rigorous knowledge they need to succeed at a technical level in their industry. Expecting them automatically to excel at managing people is at best naive and at worst quite unreasonable". Employees who excel on the scientific and technical front but not on other skills such as managing and working with others will be of much less value to organizations in the future.

According to Hazzan and Har-Shai (2013) a Google search reveals that almost all problems associated with software development processes are connected to people and are rooted not in technological aspects but in the expression of soft skills. Johnston and McGregor (2004) are of the opin- 
ion that failures associated with professional services can have serious economic and human consequences and that professionals need the professional skills and attitudes involved in recognizing other perspectives and valuing diverse contributions.

From this it can be concluded that soft skills are very important and that there is a perception that recently graduated students generally lack these important soft skills. As stated earlier, the aim of this paper is to research the perceptions of lecturers, industry, and students on soft skills and to identify important soft skills that need to be developed.

The following section summarizes information from current literature on soft skills.

\section{Literature Review}

In this literature review terminology is defined, and a list of important soft skills is compiled from literature.

\section{Terminology}

Skill has always been an elusive concept. The increasing prominence of soft skills has added to this complexity (Grugulis \& Vincent, 2009). The tacit nature of soft skills makes it difficult to observe and challenging to measure. There is no globally accepted definition of soft skills. Each discipline, educational sector and country defines soft skills according to their own needs (Kechagias, 2011).

Terminology being used include soft skills, applied skills and 21st-century skills (Gewertz, 2007) and practical intelligence (Joseph et al., 2010). Joseph et al. (2010) define the practical intelligence of professionals as the managerial, intrapersonal, and interpersonal skills that are used to resolve work problems. Other possible terms suggested for these skills include nontechnical skills, general skills, generic skills, essential skills, and employability skills (Johnston \& McGregor, 2004); and behavioural skills (Wilhelm, Logan, Smith, \& Szul, 2002). Kechagias (2011) refers to different terms being used, for instance enabling skills, generic skills, core skills, key competencies, essential skills, and necessary skills.

Although a large number of definitions may be found in the literature on the concept of skill, most emphasize that all skills are capable of being learned and developed, and involve the appropriate and observable performance of particular types of activity and tasks (Kechagias, 2011). Soft skills are defined as intra- and inter-personal skills, essential for personal development, social participation, and workplace success and should be distinguished from technical or hard skills (Kechagias, 2011). Soft skills are also defined as nontechnical skills, abilities, and traits required to function in a specific employment environment (Wilhelm et al., 2002).

Soft skills may differ, but according to Gibb (2014) they all share a common purpose and that is to improve personal development, participation in learning and success in employment. Robles (2012) writes that hard skills are the technical expertise and knowledge needed for a job while soft skills are interpersonal qualities, also known as people skills. Azim et al. (2010) refer to hard skills as processes, tools, and techniques while soft skills are seen as skills dealing with human issues or the people part of the project. Soft skills are necessary to deal with people and hard skills to analyse and predict (Azim et al., 2010).

For the purpose of this study, the term soft skills is used, and it is defined as intra- and interpersonal skills essential for personal development, social participation, and required to function in a specific employment environment. 


\section{Types of Soft Skills}

Joseph et al. (2010) write about four dimensions of soft skills (or what they call practical intelligence), namely managing tasks, managing career, managing self, and managing others (including superiors, subordinates, peers, clients, etc.). There are a core set of soft skills that are common to most all programs. These are, according to Bancino and Zevalkink (2007), face-to-face communications, nonverbal communication, active listening, writing and presentation skills, selfawareness, social awareness, relationship management, conflict management, leadership, teamwork, emotional intelligence, negotiation skills, change management, and team problem solving.

Robles (2012) identified the top 10 soft skills perceived as the most important by business executives: integrity, communication, courtesy, responsibility, social skills, positive attitude, professionalism, flexibility, teamwork, and work ethic. According to Andrews and Higson (2008) the most important transferable soft skills impacting employability of graduates are professionalism, reliability, the ability to cope with uncertainty, the ability to work under pressure, the ability to plan and think strategically, the capability to communicate and interact with others, good written and verbal communication skills, information and communication technology skills, creativity and self-confidence, good self-management and time-management skills, a willingness to learn and accept responsibility. Azim et al. (2010) emphasize most of the skills already mentioned, as can be seen in Table 1.

According to Russell et al. (2005) the soft skills most frequently enumerated by industry are effective interpersonal relations, self-management strategies, teamwork, problem-solving, and decision-making. Gewertz (2007) mentions the ability to work comfortably with people from other cultures, problem-solving, the ability to write and speak well, the ability to think in a multidisciplinary way, and the ability to evaluate information critically, as well as being punctual and dependable. Another possible list is that of González-Morales, De Antonio, and García (2011): report writing, teamwork, client management and client expectations, leadership and supervision, decision making, conflict management, critical thinking, and communication of results.

From these and other sources a list of soft skills was compiled, as can be seen in Table 1. Some of the soft skills could perhaps be combined, but are kept separate here to keep true to the original source. Skills are ordered according to the frequency with which they were mentioned in the different sources, and then alphabetically.

\begin{tabular}{|l|l|l|l|l|l|l|l|l|l|l|}
\hline \multicolumn{7}{|c|}{ Table 1 List of soft skills according to different sources from literature } \\
\hline Soft skill & & $\mathrm{X}$ & $\mathrm{X}$ & $\mathrm{X}$ & $\mathrm{X}$ & & $\mathrm{X}$ & $\mathrm{X}$ & $\mathrm{X}$ & $\mathrm{X}$ \\
\hline $\begin{array}{l}\text { Communication (verbal and } \\
\text { written) }\end{array}$ & $\mathrm{X}$ & $\mathrm{X}$ & $\mathrm{X}$ & & $\mathrm{X}$ & $\mathrm{X}$ & & $\mathrm{X}$ & $\mathrm{X}$ & $\mathrm{X}$ \\
\hline Teamwork & & $\mathrm{X}$ & $\mathrm{X}$ & $\mathrm{X}$ & & & & $\mathrm{X}$ & $\mathrm{X}$ \\
\hline Professionalism & $\mathrm{X}$ & $\mathrm{X}$ & $\mathrm{X}$ & & & & & $\mathrm{X}$ & \\
\hline $\begin{array}{l}\text { Flexibility / ability to cope } \\
\text { with uncertainty }\end{array}$ & $\mathrm{X}$ & $\mathrm{X}$ & $\mathrm{X}$ & & $\mathrm{X}$ & & & & \\
\hline Interpersonal relations & $\mathrm{X}$ & & & $\mathrm{X}$ & & & $\mathrm{X}$ & & $\mathrm{X}$ \\
\hline Leadership & $\mathrm{X}$ & & & & $\mathrm{X}$ & $\mathrm{X}$ & & & $\mathrm{X}$ \\
\hline Problem-solving & & $\mathrm{X}$ & $\mathrm{X}$ & & & $\mathrm{X}$ & & $\mathrm{X}$ & \\
\hline Responsibility / reliability & & $\mathrm{X}$ & & $\mathrm{X}$ & & & & $\mathrm{X}$ & $\mathrm{X}$ \\
\hline Work ethic / Integrity & & & & $\mathrm{X}$ & & & $\mathrm{X}$ & & \\
\hline Conflict management & $\mathrm{X}$ & $\mathrm{X}$ & & & & & & & $\mathrm{X}$ \\
\hline Courtesy & & & $\mathrm{X}$ & & & & & & $\mathrm{X}$ \\
\hline Creativity & & & & & & & & & \\
\hline
\end{tabular}




\begin{tabular}{|c|c|c|c|c|c|c|c|c|c|}
\hline \multicolumn{10}{|c|}{ Table 1 List of soft skills according to different sources from literature } \\
\hline Soft skill & 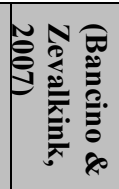 & 苍尽 & 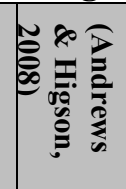 & 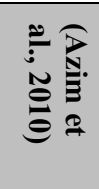 & 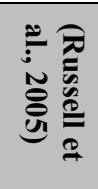 & 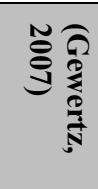 & 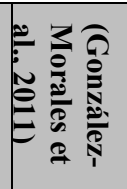 & 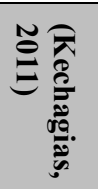 & 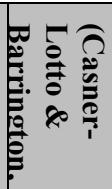 \\
\hline Critical thinking & & & & & & $\mathrm{X}$ & $\mathrm{X}$ & & \\
\hline Decision-making & & & & & $\mathrm{X}$ & & $\mathrm{X}$ & & \\
\hline Negotiation & $\mathrm{X}$ & & & $\mathrm{X}$ & & & & & \\
\hline Self-confidence & & & $\mathrm{X}$ & & & & & & $\mathrm{X}$ \\
\hline Self-management & & & $\mathrm{X}$ & & & & & & $\mathrm{X}$ \\
\hline $\begin{array}{l}\text { Time-management / punctu- } \\
\text { ality }\end{array}$ & & & $\mathrm{X}$ & & & & & & $\mathrm{X}$ \\
\hline Willingness to learn & & & $\mathrm{X}$ & & & & & & $\mathrm{X}$ \\
\hline Client management & & & & & & & $\mathrm{X}$ & & \\
\hline Cross-cultural relationships & & & & & & $\mathrm{X}$ & & & \\
\hline Emotional intelligence & $\mathrm{X}$ & & & & & & & & \\
\hline Handling pressure & & & $\mathrm{X}$ & & & & & & \\
\hline Multi-disciplinary thinking & & & & & & $\mathrm{X}$ & & & \\
\hline Positive attitude & & $\mathrm{X}$ & & & & & & & \\
\hline
\end{tabular}

\section{Development of Soft Skills}

Soft skills are necessary for an individual to communicate, work as a member of a team, inspire confidence, and understand and adapt to the cultural norms of the workplace (Wilhelm et al., 2002). The nature of IT professionals' jobs are changing, and because of this job roles, required skills, and personal attributes required for successful IT employees are changing (Gallivan, Truex III, \& Kvasny, 2004). Trauth, Farwell, and Lee (1993) also writes that career paths of IS professionals are changing because of restructuring of IS activities. A study by Lee, Trauth, and Farwell (1995) showed that respondents considered technical specialties knowledge to be the least important, for both now and in the future, and business functional knowledge and interpersonal/ management skills the most important in the future. IS managers with sufficient human relations and management training and who can communicate effectively remain a necessary, important but scarce resource (Trauth et al., 1993).

According to a study by Wynekoop and Walz (2000) exceptional personnel are distinguished by the following abilities:

- the ability to abstract business problems,

- creativity,

- technical and business knowledge,

- the ability to work with, and lead, teams,

- analytical and logical abilities,

- high levels of self-motivation, and

- dependability.

Graduates who intend to work in user areas require a strong background in business management and human relations. The challenge for educators and educational institutions is to change the curriculum to accommodate teaching and learning for this diversity of career paths (Lee et al., 1995). IS students can benefit from formal training / education in creative problem solving, leadership, and communication skills (Wynekoop \& Walz, 2000). Even though maintaining a productive relationship with the user/client is viewed by many practitioners as the most important of skills, it apparently receives little attention in the classroom (Trauth et al., 1993). 
Soft skills require a different strategy for both teaching and evaluating than other skills (Wilhelm et al., 2002). There is not a single best approach for teaching soft skills, as the most appropriate one depends on the context under which the teaching is taking place, the specific goals of the program, and the discipline (Kechagias, 2011). Hazzan and Har-Shai (2013) write that soft skills cannot be studied and taught formally and, rather, should be learned and over a period of time, based on students' engagement, active learning, and reflection.

Research by Joseph, Ang, and Slaughter (1999) showed that there is a difference between the soft skills of experienced I/S professionals and inexperienced undergraduates, suggesting that exposure to work situations is extremely important in developing soft skills. Real-world examples can also help students relate to the importance of soft skills (Bancino \& Zevalkink, 2007).

Recommendations for the development of soft skills are the following (Russell et al., 2005):

- Encourage students to dialog with others by outcomes that include a short presentation, short panel discussion, or in-class Question and Answer sessions.

- Students must be required to work cooperatively with others toward a common goal.

- Instructors should strive to find learning outcomes that involve teaming, leadership, presentations, interviews, or panel discussions. Teaming builds both leadership skills and an ability to listen and follow the leadership of others.

To summarize, according to available literature, soft skills are very important, but difficult to teach. Recommendations from literature for the teaching and learning of soft skills are engagement of students, active learning, reflection, exposure to work situations, real-world examples, encouraging dialog, cooperative work with a common goal, and striving to find learning outcomes involving leadership, teaming, presentations, discussions, etc.

\section{Methodology}

\section{Data Gathering and Analysis}

The research was done at a university in South Africa. After the literature review was done, a questionnaire was created. The questionnaire consisted of open questions, and qualitative analysis was done on the results. All of the questionnaires were distributed and received back during the months October and November of 2015. Qualitative analysis was chosen because the aim was to gain a deeper understanding of the situation.

Questionnaire 1 (Industry) consisted of five questions:

- Which five of the mentioned soft skills (or others not listed) do you think are most important for IT-graduates in the working environment? List in order of importance.

- Do you think these soft skills are developed sufficiently during the students' university education?

Yes / No. Please motivate your answer.

- With which of the soft skills do graduates have the biggest problem?

- How can these skills be improved at university level - any suggestions?

- Any other comments on this topic?

This questionnaire was e-mailed to twenty-five IT companies who have previously employed our students. Twelve responses were received.

Questionnaire 2 (Lecturers) had the following additional question for each module they teach: 
- List the modules you teach and indicate which soft skills, if any, are developed in each module.

This questionnaire was e-mailed to the eleven lecturers responsible for teaching and learning of IT subjects All of the lecturers answered the questions.

Questionnaire 3 (Students) had the following additional question:

- Which soft skills were developed in the program you followed (graduate and post graduate)? Indicate specific modules as well where possible.

This questionnaire was e-mailed to the thirty-nine students who have recently completed their post graduate studies in IT at the Potchefstroom Campus. Ten responses were received.

\section{Results}

In this section the results of the different questionnaires are described under the headings perception of lecturers, perception of industry and perception of students.

\section{Perception of Lecturers}

Feedback from lecturers is described under the following headings: the most important soft skills according to lecturers, the perception of the development of these soft skills, and the soft skills where the biggest shortcomings exist according to the lecturers. This is followed by a list of soft skills developed in the different subject areas that form part of the IT-program.

\section{Most important soft skills according to lecturers}

In Table 2 a list can be seen of the soft skills lecturers thought most important. Soft skills are ordered according to the frequency with which they were mentioned in the responses from lecturers. Respondents had to list the soft skills in order of importance (1-5). These rankings are also shown in the table.

\begin{tabular}{|l|l|l|l|l|l|l|l|l|l|l|}
\hline \multicolumn{1}{|c|}{ Table 2 Most important soft skills according to lecturers (N = 10) } \\
\hline Skill & $\mathbf{1 - 5}$ & $\mathbf{1 - 5}$ & $\mathbf{1 - 5}$ & $\mathbf{1 - 5}$ & $\mathbf{1 - 5}$ & $\mathbf{1 - 5}$ & $\mathbf{1 - 5}$ & $\mathbf{1 - 5}$ & $\mathbf{1 - 5}$ & $\mathbf{1 - 5}$ \\
\hline Communication (verbal and written) & 1 & 1 & 3 & 1 & 1 & 2 & 1 & 1 & 1 & 1 \\
\hline Work ethic & 3 & 1 & 1 & 2 & 5 & 2 & 3 & & & \\
\hline Multi disciplinary thinking & 5 & 4 & 5 & 3 & 5 & & & & & \\
\hline Self-management & 4 & 5 & 3 & 3 & 2 & & & & & \\
\hline Decision making & 4 & 3 & 5 & 5 & & & & & & \\
\hline Teamwork & 2 & 1 & 3 & 5 & & & & & & \\
\hline Interpersonal relations & 4 & 4 & 2 & & & & & & & \\
\hline Conflict management & 5 & 5 & & & & & & & & \\
\hline Eagerness to learn & 3 & 2 & & & & & & & & \\
\hline Flexibility & 2 & 3 & & & & & & & & \\
\hline Leadership & 2 & 2 & & & & & & & & \\
\hline Negotiation & 4 & 4 & & & & & & & & \\
\hline Professionalism & 3 & 5 & & & & & & & & \\
\hline Self confidence & 4 & 2 & & & & & & & & \\
\hline Client management & 4 & & & & & & & & & \\
\hline Positive attitude & 4 & & & & & & & & & \\
\hline Time management & 4 & & & & & & & & & \\
\hline
\end{tabular}




\section{Perception of the Development of Soft Skills According to Lecturers}

The lecturers were asked if the soft skills are developed adequately during the students' university studies. Only one lecturer answered yes. Six answered no and four were unsure. These lecturers felt that some of the soft skills are developed but not all of them.

Some interesting comments were:

"It is the responsibility of the student to give attention to developing these skills on a daily basis".

"The skills are not always developed as expected because students do not always do what is expected of them".

"It is still not enough although, in my opinion, we do more than most subject groups or universities to develop these skills".

"There isn't enough time to focus on all the necessary skills".

"Most of these skills are not developed in the class room but outside of the classroom where, for instance, team work is done".

"The size of groups has a negative impact on the development of soft skills. Not enough attention can be given to each student to develop and evaluate soft skills".

"Students should complete more assignments in teams. Assignments should consist of parts that are inter-dependant".

"The students grow up with the perception that it is good enough to do the minimum to pass. They should be motivated to always do their best".

\section{Soft skills where the biggest shortcomings exist according to the lecturers}

Verbal and written communication was mentioned by six lecturers and work ethics and self management by three. Team work was mentioned twice. Willingness to learn, negotiation, decisionmaking, client management, professionalism, and time management were also mentioned.

Interesting comments were:

"Development of soft skills differs from student to student according to experience and maturity".

"Students don't do what was asked of them but what they are comfortable with. They do not have the necessary respect for others. Lecturers have to make sure that students learn to follow the rules. This will help with soft skills, e.g., communication, work ethics and self management".

"Lecturers do not always have time to teach these soft skills as well as the relevant technical skills. Students can be encouraged to do short courses on soft skills".

"Maybe we should get feedback from industry and alumni to identify soft skills that are seen as problem areas. We can also use experts to present lecturers and workshops".

\section{Soft skills being taught in the IT-program according to lecturers}

Lecturers were asked which soft skills are, according to them, developed in the modules they teach. Lecturers responded for 23 different subject areas that form part of the graduate and post graduate program. Soft skills mentioned were communication (mentioned 14 times), selfmanagement (11), teamwork (10), interpersonal relations (9), conflict management (9), leadership (6), decision making (4), work ethic (4), multi disciplinary thinking (4), professionalism (2), negotiation (2), flexibility (2), cross cultural relationships and self confidence. 


\section{Perceptions of Industry}

Feedback from industry is described under the following headings: the most important soft skills according to industry, the perception of the development of these soft skills, the skills where the biggest shortcomings exist according to the industry, and suggestions from industry for improvement of soft skills.

\section{Most important soft skills according to industry}

In Table 3 a list can be seen of the soft skills industry thought most important. Soft skills are ordered according to the frequency with which they were mentioned in the responses from industry. Respondents had to list the soft skills in order of importance (1-5). These rankings are also shown in the table.

\begin{tabular}{|l|l|l|l|l|l|l|l|l|l|l|l|l|}
\hline \multicolumn{10}{|c|}{ Table 3 Most important soft skills according to industry (N = 11) } \\
\hline Skill & $\mathbf{1 - 5}$ & $\mathbf{1 - 5}$ & $\mathbf{1 - 5}$ & $\mathbf{1 - 5}$ & $\mathbf{1 - 5}$ & $\mathbf{1 - 5}$ & $\mathbf{1 - 5}$ & $\mathbf{1 - 5}$ & $\mathbf{1 - 5}$ & $\mathbf{1 - 5}$ & $\mathbf{1 - 5}$ \\
\hline $\begin{array}{l}\text { Communication (verbal and writ- } \\
\text { ten) }\end{array}$ & 4 & 4 & 2 & 5 & 5 & 1 & 1 & 2 & 5 & 1 & 1 \\
\hline Flexibility & 3 & 1 & 2 & 4 & 4 & 4 & 4 & & & & \\
\hline Self-management & 2 & 5 & 4 & 1 & 5 & 4 & & & & & \\
\hline Teamwork & 1 & 3 & 3 & 1 & 2 & & & & & & \\
\hline Multi-disciplinary thinking & 4 & 5 & 5 & 3 & 5 & & & & & & \\
\hline Client management & 3 & 3 & 2 & 1 & & & & & & & \\
\hline Decision making & 5 & 4 & 1 & 3 & & & & & & & \\
\hline Conflict management & 1 & 3 & 2 & & & & & & & & \\
\hline Work ethic & 2 & 2 & 4 & & & & & & & & \\
\hline Interpersonal relations & 5 & 3 & & & & & & & & & \\
\hline Negotiation & 4 & 3 & & & & & & & & & \\
\hline Self confidence & 5 & 3 & & & & & & & & & \\
\hline Critical thinking & 2 & & & & & & & & & & \\
\hline Emotional intelligence & 2 & & & & & & & & & & \\
\hline Professionalism & 1 & & & & & & & & & & \\
\hline
\end{tabular}

\section{Perception of the development of soft skills according to industry}

Seven of the twelve respondents from industry indicated that the skills are not developed adequately at university. Three disagreed and felt that the soft skills are indeed up to standard. Two were conflicted.

Interesting comments:

"Students who completed the post graduate year do very good to adapt to the working environment. The students we employ from your campus are definitely better than the average student from other universities. You do good work with these students".

"Students do not learn good time management".

"Due to the nature of university most of the projects that students will work on will be preplanned and have a set road map. Which is understandable because at the end of the day students need to be award marks for work which can be compared back to some type of standard or mark sheet. However in the work environment, requirements for projects will change, be ambiguous and be misinterpreted between parties. This results in the need for client management, negotiation and flexibility. This also results inadvertently in the potential for ethical decision like the 
most common "do we let the client know about this...". It will be very hard for a university program to replicate this type of environment".

"Yes and No, I believe that a lot of the soft skills are addressed, such as communication and team work. I do however feel there is room for improvement for emotional intelligence, which is very difficult to teach and for multi-disciplinary thinking, which is often a problem for IT graduates".

"From my experience it seems that team work and communication are well developed. The bigger problem is email communication that tends to be the lifeblood of communication in industry but most graduates prefer using whatsapp, skype and social media for communication. I however think it is industry that has to adapt here".

"In the industry a large part of each day is spent on communication (e-mail, meetings, etc.). The quality of this communication determines how effective your work is done. In comparison, most of your time at university is spent on own studies and assignments. Teamwork is the exception, but then all team members usually have the same background and skills".

"No, we find well qualified individuals battling with these basic skills on an ongoing basis. Graduates are largely immature when they arrive at the workplace and a lot more can be done at university to address this".

\section{Soft skills where the biggest shortcomings exist according to the industry}

Communication was mentioned four times, conflict management and multi-disciplinary thinking three times, client management and flexibility two times, and self management, cross-cultural relationships, decision making and emotional intelligence were also mentioned. Communication in English was mentioned specifically (as our students are taught mainly in their mother tongue, Afrikaans).

\section{Suggestion from industry for improvement of soft skills}

One suggestion was that students should work in the industry during the holidays. Another suggestion was that students should work with students from other faculties.

Interesting comments were: "IT students should get a better understanding of the industry so that they know what to expect and what will be expected from them. This will help for the preparation."

"Give students' real world projects with real world clients or maybe try and define a project that will have change, but the change is based off the actions taken by the students".

"The challenge here is to get the individual solving the problem to think wider, evaluate the pro's and con's of more options before implementing anything, and even then to keep an open mind and not "fall in love" with the solution they selected. Get the individual tasked with finding a solution to present it to a panel that can challenge it. The more practical application experienced the better".

"Different roles will need different skills. For a software developer decision making will be more critical while others may need multi-disciplinary thinking more. Each role has a specific communication style, for instance more detail-orientated versus more timeline-orientated".

"I think the problem speak for itself. We have been sending new employees for elocution lessons and we have found that more often than not the very basics are missing. We find graduates from rural schools have above average ability and results at university, but when placed in a work environment the problem with communication make them introverted and stunts their growth opportunity". 


\section{Perceptions of Students}

Feedback from students is described under the following headings: the most important soft skills according to the students, soft skills where the biggest shortcomings exist according to the students, and suggestions from students for improvement of soft skills. A list is also compiled of the students' perception on which soft skills were developed in different subject groups during their studies.

\section{Most important soft skills according to students}

In Table 4 a list can be seen of the soft skills students thought most important. Soft skills are ordered according to the frequency with which they were mentioned in the responses from students. Respondents had to list the soft skills in order of importance (1-5). These rankings are also shown in the table.

\begin{tabular}{|l|l|l|l|l|l|l|l|l|l|l|}
\hline \multicolumn{1}{|c|}{ Table 4 Most important soft skills according to students (N = 10) } \\
\hline Skill & $\mathbf{1 - 5}$ & $\mathbf{1 - 5}$ & $\mathbf{1 - 5}$ & $\mathbf{1 - 5}$ & $\mathbf{1 - 5}$ & $\mathbf{1 - 5}$ & $\mathbf{1 - 5}$ & $\mathbf{1 - 5}$ & $\mathbf{1 - 5}$ & $\mathbf{1 - 5}$ \\
\hline Communication & 1 & 1 & 1 & 2 & 1 & 1 & 1 & 2 & 1 & 1 \\
\hline Team work & 2 & 3 & 1 & 4 & 4 & 2 & 1 & 5 & & \\
\hline Decision making & 3 & 5 & 4 & 3 & 3 & & & & & \\
\hline Self management & 4 & 5 & 2 & 2 & 5 & & & & & \\
\hline Flexibility & 3 & 5 & 4 & 3 & & & & & & \\
\hline Professionalism & 3 & 3 & 5 & & & & & & & \\
\hline Work ethic & 2 & 5 & 2 & & & & & & & \\
\hline Client management & 2 & 5 & & & & & & & & \\
\hline Integrity & 5 & 4 & & & & & & & & \\
\hline Leadership & 4 & 4 & & & & & & & & \\
\hline Multi-disciplinary thinking & 5 & 3 & & & & & & & & \\
\hline Conflict management & 4 & & & & & & & & & \\
\hline Interpersonal relations & 2 & & & & & & & & & \\
\hline Negotiation & 4 & & & & & & & & & \\
\hline Self confidence & 3 & & & & & & & & & \\
\hline
\end{tabular}

\section{Soft skills where the biggest shortcomings exist according to the students}

Multi-disciplinary thinking and communication were each mentioned six times. Conflict management, client management, self confidence and self management were each mentioned twice. Other soft skills mentioned were decision making, team work and flexibility.

\section{Suggestion from students for improvement of soft skills}

Interesting comments were:

"When completing projects, combine them with other courses to give a better idea of what will happen in the industry. Example for the project subject in the $3^{\text {rd }}$ year when students need to develop a website, collaborate with a design student to give a better idea on how to bring the front end and back end design together".

"By using realistic projects scenarios - not receiving the project with all the requirements etc on paper beforehand but consulting the clients etc to discover the requirements". 


\section{Soft skills being taught in the IT-program according to students}

Students were asked which soft skills are, according to them, developed during their studies. Soft skills mentioned were communication, self-management, interpersonal relations, teamwork, professionalism, decision-making, flexibility, work ethic, leadership, client management, crossculture relationships, and conflict management.

\section{Discussion of Results}

This sections starts with a list of the most important skills according to literature, lecturers, industry and students. Perceptions of lecturers and industry on whether the soft skills are developed adequately are discussed. The soft skills listed as those where students have the biggest shortcomings are described. The section ends with suggestions (from industry and students) on how the soft skills can be improved.

\section{List of Most Important Soft Skills According to Literature, Lecturers, Industry and Students}

The important soft skills identified by lecturers, industry, and students are very similar. All of the soft skills mentioned are on the list compiled from literature (Table 1). Soft skills on the original list (Table 1) that are not mentioned by lecturers, industry, or students as most important are the following:

- Cross-cultural relationships. Cross-cultural relationships is, however, mentioned by lecturers and students as one of the skills being taught, and also by industry as one of the soft skills students are most lacking of.

- Responsibility. This could be seen as part of, and already addressed by, soft skills such as time management, self management, work ethic, etc.

- Problem-solving. This could be seen as part of, and already addressed by, soft skills such as critical thinking, multi-disciplinary thinking, etc. Also may be partly seen as a technical or hard skill?

- Courtesy. One of the lecturers made a comment about students lacking respect ("They do not have the necessary respect for others".). This may be seen as a reference to students lacking the skill of courtesy. This could, however, also be seen as already addressed by soft skills such as interpersonal relations, communication, conflict management, etc.

- Creativity. This could be seen as part of, and already addressed by, soft skills such as critical thinking, multi-disciplinary thinking etc.

- Handling pressure. This could be seen as part of, and already addressed by, soft skills such as time management, self management, work ethic, flexibility, etc.

Using this feedback, a list is compiled of most important soft skills according to literature, lecturers, industry, and students. This list can be seen in Table 5. Soft skills are sorted alphabetically. In columns 2, 3, 4 and 5 it is indicated whether each soft skills was mentioned by literature, lecturers, industry, and/ or students. In column 6 it is indicated whether, according to the lecturers, the specific soft skill is taught in one of the subject areas. In column 7 it is indicated whether, according to the students, the specific soft skill is taught in one of the subject areas. 


\begin{tabular}{|l|l|l|l|l|l|l|l|}
\hline \multicolumn{2}{|c|}{ Table 5 List of important soft skills according to literature, lecturers, industry and students } \\
\hline Soft skill & Literature & Lecturers & Industry & Students & $\begin{array}{l}\text { Taught (ac- } \\
\text { cording to } \\
\text { lecturers }\end{array}$ & $\begin{array}{l}\text { Taught (ac- } \\
\text { cording to } \\
\text { students) }\end{array}$ \\
\hline Client management & $\mathrm{X}$ & $\mathrm{X}$ & $\mathrm{X}$ & $\mathrm{X}$ & & $\mathrm{X}$ \\
\hline $\begin{array}{l}\text { Communication } \\
\text { (verbal and written) }\end{array}$ & $\mathrm{X}$ & $\mathrm{X}$ & $\mathrm{X}$ & $\mathrm{X}$ & $\mathrm{X}$ & $\mathrm{X}$ \\
\hline $\begin{array}{l}\text { Conflict manage- } \\
\text { ment }\end{array}$ & $\mathrm{X}$ & $\mathrm{X}$ & $\mathrm{X}$ & $\mathrm{X}$ & $\mathrm{X}$ & $\mathrm{X}$ \\
\hline Critical thinking & $\mathrm{X}$ & & $\mathrm{X}$ & & & $\mathrm{X}$ \\
\hline $\begin{array}{l}\text { Cross-cultural rela- } \\
\text { tionships }\end{array}$ & $\mathrm{X}$ & $\mathrm{X}$ & & & $\mathrm{X}$ & \\
\hline Decision-making & $\mathrm{X}$ & $\mathrm{X}$ & $\mathrm{X}$ & $\mathrm{X}$ & $\mathrm{X}$ & $\mathrm{X}$ \\
\hline $\begin{array}{l}\text { Emotional intelli- } \\
\text { gence }\end{array}$ & $\mathrm{X}$ & & $\mathrm{X}$ & & & $\mathrm{X}$ \\
\hline $\begin{array}{l}\text { Flexibility / ability } \\
\text { to cope with uncer- } \\
\text { tainty }\end{array}$ & $\mathrm{X}$ & $\mathrm{X}$ & $\mathrm{X}$ & $\mathrm{X}$ & $\mathrm{X}$ & \\
\hline $\begin{array}{l}\text { Interpersonal rela- } \\
\text { tions }\end{array}$ & $\mathrm{X}$ & $\mathrm{X}$ & $\mathrm{X}$ & $\mathrm{X}$ & $\mathrm{X}$ & $\mathrm{X}$ \\
\hline Leadership & $\mathrm{X}$ & $\mathrm{X}$ & & $\mathrm{X}$ & $\mathrm{X}$ & $\mathrm{X}$ \\
\hline $\begin{array}{l}\text { Multi-disciplinary } \\
\text { thinking }\end{array}$ & $\mathrm{X}$ & $\mathrm{X}$ & $\mathrm{X}$ & $\mathrm{X}$ & $\mathrm{X}$ & \\
\hline Negotiation & $\mathrm{X}$ & $\mathrm{X}$ & $\mathrm{X}$ & $\mathrm{X}$ & $\mathrm{X}$ & $\mathrm{X}$ \\
\hline Positive attitude & $\mathrm{X}$ & $\mathrm{X}$ & $\mathrm{X}$ & $\mathrm{X}$ & $\mathrm{X}$ & $\mathrm{X}$ & \\
\hline Professionalism & $\mathrm{X}$ & $\mathrm{X}$ & $\mathrm{X}$ & $\mathrm{X}$ & $\mathrm{X}$ \\
\hline Self-confidence & $\mathrm{X}$ & $\mathrm{X}$ & $\mathrm{X}$ & $\mathrm{X}$ & $\mathrm{X}$ & \\
\hline Self-management & $\mathrm{X}$ & $\mathrm{X}$ & $\mathrm{X}$ & $\mathrm{X}$ & $\mathrm{X}$ & $\mathrm{X}$ \\
\hline Teamwork & $\mathrm{X}$ & $\mathrm{X}$ & $\mathrm{X}$ & $\mathrm{X}$ & $\mathrm{X}$ & \\
\hline $\begin{array}{l}\text { Time-management / } \\
\text { punctuality }\end{array}$ & $\mathrm{X}$ & $\mathrm{X}$ & & & $\mathrm{X}$ & \\
\hline Willingness to learn & $\mathrm{X}$ & $\mathrm{X}$ & & & $\mathrm{X}$ & \\
\hline $\begin{array}{l}\text { Work ethic / Integri- } \\
\text { ty }\end{array}$ & $\mathrm{X}$ & $\mathrm{X}$ & $\mathrm{X}$ & $\mathrm{X}$ & \\
\hline
\end{tabular}

Eleven of the twenty skills are, according to lecturers as well as students, taught in one or more of the subject areas (as can be seen from the results in Table 5). These are communication, conflict management, cross-cultural relationships, decision-making, flexibility, interpersonal relations, leadership, professionalism, self-management, teamwork, and work ethic. According to lecturers (but not students) multi-disciplinary thinking, negotiation, and self-confidence are taught. According to students (but not indicated by lecturers) client management is taught.

Soft skills that are not taught according to lecturers or students are critical thinking, emotional intelligence, positive attitude, time management, and willingness to learn. It may be argued that soft skills are also highly linked to personality types, especially emotional intelligence, positive attitude, and willingness to learn. Critical thinking should automatically be developed in any higher education program, and it is possible that it was not mentioned because this was assumed. Time management could also be seen as part of self-management. 


\section{Is the development of soft skills adequate?}

Ten out of eleven lecturers answered no. Seven of the twelve respondents from industry indicated that the skills are not developed adequately at university. This shows that this is an important issue and that further research is necessary to address this.

It was good to receive some positive comments:

"It is still not enough although, in my opinion, we do more than most subject groups or universities to develop these skills".

"The students we employ from your campus are definitely better than the average student from other universities. You do good work with these students".

"I believe that a lot of the soft skills are addressed, such as communication and team work".

"From my experience it seems that team work and communication are well developed".

There are, however, still many areas in need of attention. This quote may be representative of most of the feedback from industry:

"No, we find well qualified individuals battling with these basic skills on an ongoing basis. Graduates are largely immature when they arrive at the workplace and a lot more can be done at university to address this".

Comments also emphasized some of the difficulties in the development of soft skills:

"It will be very hard for a university program to replicate this type of environment".

"I do however feel there is room for improvement for emotional intelligence, which is very difficult to teach".

"It is the responsibility of the student to give attention to developing these skills on a daily basis".

"The skills are not always developed as expected because students do not always do what is expected of them".

"I however think it is industry that has to adapt here".

"There isn't enough time to focus on all the necessary skills".

"The size of groups has a negative impact on the development of soft skills. Not enough attention can be given to each student to develop and evaluate soft skills".

From the above comments it can be seen that there is a difference of opinion on where the responsibility for developing soft skills lie (student, lecturers, or industry?), and that time constraints and large groups are seen as part of the problem.

\section{Biggest Shortcomings}

Lecturers, industry, and students were asked to list soft skills where, according to them, the biggest shortcomings exist. In Table 6 the results can be seen. In the first column the soft skills from Table 5 are listed. In the second, third and fourth columns can be seen how many respondents mentioned the specific skill as a problem (if any). 


\begin{tabular}{|l|l|l|l|}
\hline \multicolumn{5}{|l|}{ Table 6. Shortcomings } \\
\hline Soft skill & $\begin{array}{l}\text { Lecturers } \\
(\mathbf{N}=\mathbf{1 1})\end{array}$ & $\begin{array}{l}\text { Industry } \\
(\mathbf{N}=\mathbf{1 2})\end{array}$ & $\begin{array}{l}\text { Students } \\
(\mathbf{N}=10)\end{array}$ \\
\hline Client management & 1 & 2 & 2 \\
\hline Communication (verbal and written) & 6 & 4 & 6 \\
\hline Conflict management & & 3 & 2 \\
\hline Critical thinking & & & \\
\hline Cross-cultural relationships & & 1 & \\
\hline Decision-making & 1 & 1 & 1 \\
\hline Emotional intelligence & & 1 & \\
\hline Flexibility / ability to cope with uncertainty & & 2 & 1 \\
\hline Interpersonal relations & & & \\
\hline Leadership & & & \\
\hline Multi-disciplinary thinking & & 3 & 6 \\
\hline Negotiation & 1 & & \\
\hline Positive attitude & & & \\
\hline Professionalism & 1 & & \\
\hline Self-confidence & & & 2 \\
\hline Self-management & 3 & 1 & 2 \\
\hline Teamwork & 2 & & 1 \\
\hline Time-management / punctuality & 1 & & \\
\hline Willingness to learn & 1 & & \\
\hline Work ethic / Integrity & 3 & & \\
\hline
\end{tabular}

Only four of these soft skills are not mentioned in any of the responses. These are critical thinking, interpersonal relationships, leadership, and positive attitude. There is a difference in the perceptions of lecturers, industry, and students on which soft skills are not developed adequately and further research is needed on this. The only soft skills on which lecturers, industry, and students agree as problem areas are client management, communication, decision making, and selfmanagement.

\section{Suggestions for Development of Soft Skills}

Suggestions were the following:

- Students should work in the industry during holidays.

- Students should work with students from other courses or faculties.

- Students should get a better understanding of the industry and what is expected of them.

- Students should work on real world projects with real world clients.

- Use experts to present lecturers and workshops.

- Motivate students to do their best to excel.

- More teamwork must be done; especially on projects were components of the assignment are inter-dependant.

- When students work in a team, they must assume different roles so that a student can not choose to do only that which he is comfortable with.

- Interactive lectures will help with the development of communication skills. 


\section{Conclusions}

The term soft skills is defined as intra- and inter-personal skills, essential for personal development, social participation, and required to function in a specific employment environment. Available literature shows that there is a perception that recently graduated students generally lack these important soft skills. The results of this study correlates with what was found during the literature study, showing that most lecturers and respondents from the industry feel that the soft skills of the students are not developed adequately.

In the literature review many different skills were mentioned (see Table 1 for list from literature review) and sources mentioned employers being concerned about different skills not being developed as they should be. The results of this study confirm what was found in literature. Most of the soft skills mentioned were identified by the participants in this study as areas where big shortcomings exist. This shows that this is an important issue and that further research is necessary to address this.

According to available literature, soft skills are difficult to teach. This is confirmed by the results of this study showing that soft skills are seen as difficult to teach because of factors such as time constraints and large groups. This is further complicated by a difference of opinion on where the responsibility for developing soft skills lie (student, lecturers, or industry?).

Recommendations from this study for the teaching and learning of soft skills correlate with the recommendations from literature, namely that students should work in the industry during holidays (exposure to work situations), students should work with students from other courses or faculties (cooperative work), students should work on real world projects with real world clients (real-world examples), more teamwork must be done, and interactive lectures should be used to develop communication skills (engagements of students, active learning and encouragement of dia$\log$ ). Other recommendations from participants in this study were using experts to present lecturers and workshops, motivating students to do their best to excel, and students assuming different roles so that a student can not choose to do only that which he or she is comfortable with.

The lists of important soft skills (Table 5 and Table 6) were compiled using the results of the literature review as well as the results of this study. The soft skills listed were client management, communication (verbal and written), conflict management, critical thinking, cross-cultural relationships, decision-making, emotional intelligence, flexibility / ability to cope with uncertainty, interpersonal relations, leadership, multi-disciplinary thinking, negotiation, positive attitude, professionalism, self-confidence, self-management, teamwork, time-management / punctuality, willingness to learn, work ethic / integrity. These lists can be used to identify problem areas that need to be addressed and to guide further research.

Future work can include larger groups of students and more respondents from industry, comparing results from participants from different institutions and other countries, and quantitative analysis (using mixed methods for richer results).

\section{References}

Adomssent, M., Godemann, J., Michelsen, G., Barth, M., Godemann, J., Rieckmann, M., \& Stoltenberg, U. (2007). Developing key competencies for sustainable development in higher education. International Journal of Sustainability in Higher Education, 8(4), 416-430.

Andrews, J., \& Higson, H. (2008). Graduate employability, 'soft skills' versus 'hard'business knowledge: A European study. Higher Education in Europe, 33(4), 411-422.

Azim, S., Gale, A., Lawlor-Wright, T., Kirkham, R., Khan, A., \& Alam, M. (2010). The importance of soft skills in complex projects. International Journal of Managing Projects in Business, 3(3), 387-401. 
Bancino, R., \& Zevalkink, C. (2007). Soft skills: The new curriculum for hard-core technical professionals. Techniques: Connecting Education and Careers (J1), 82(5), 20-22.

Casner-Lotto, J., \& Barrington, L. (2006). Are they really ready to work? Employers' perspectives on the basic knowledge and applied skills of new entrants to the 21st Century US workforce: ERIC.

Douglas, M. (2002). Why'soft skills' are an essential part of hard world of business. The British Journal of Administrative Management, (34), 34.

Gallivan, M. J., Truex, D. P., III, \& Kvasny, L. (2004). Changing patterns in IT skill sets 1988-2003: A content analysis of classified advertising. ACM SIGMIS Database, 35(3), 64-87.

Gewertz, C. (2007). Soft skills in big demand. Education Week, 26(40), 25-27.

Gibb, S. (2014). Soft skills assessment: Theory development and the research agenda. International Journal of Lifelong Education, 33(4), 455-471.

González-Morales, D., De Antonio, L. M. M., \& García, J. L. R. (2011). Teaching "Soft” skills in software engineering. Paper presented at the Global Engineering Education Conference (EDUCON), 2011 IEEE.

Grugulis, I., \& Vincent, S. (2009). Whose skill is it anyway? Soft'skills and polarization. Work, Employment \& Society, 23(4), 597-615.

Hazzan, O., \& Har-Shai, G. (2013). Teaching computer science soft skills as soft concepts. Paper presented at the 44th ACM Technical Symposium on Computer Science Education.

Johnston, S., \& McGregor, H. (2004). Recognising and supporting a scholarship of practice: Soft skills are hard! In Creating Flexible Learning Environments: Proceedings of the 15th Australasian Conference for the Australasian Association for Engineering Education and the 10th Australasian Women in Engineering Forum (p. 68). Australasian Association for Engineering Education.

Joseph, D., Ang, S., Chang, R. H., \& Slaughter, S. A. (2010). Practical intelligence in IT: Assessing soft skills of IT professionals. Communications of the ACM, 53(2), 149-154.

Joseph, D., Ang, S., \& Slaughter, S. (1999). Soft skills and creativity in IS professionals. Paper presented at the Systems Sciences, 1999. HICSS-32. Proceedings of the 32nd Annual Hawaii International Conference on.

Kechagias, K. (2011). Teaching and assessing soft skills. MASS Project, September.

Klaus, P. (2010). Communication breakdown. California Job Journal, 28, 1-9.

Lee, D. M., Trauth, E. M., \& Farwell, D. (1995). Critical skills and knowledge requirements of IS professionals: A joint academic/industry investigation. MIS Quarterly, 19(3),313-340.

Noll, C., \& Wilkins, M. (2002). Critical skills of IS professionals: A model for curriculum development. Journal of Information Technology Education: Research, 1(1), 143-154. Retrieved from http://www.jite.org/documents/Vol1/v1n3p143-154.pdf

Robles, M. M. (2012). Executive perceptions of the top 10 soft skills needed in today's workplace. Business Communication Quarterly, 75(4), 453-465.

Russell, J., Russell, B., \& Tastle, W. J. (2005). Teaching soft skills in a systems development capstone class. Information Systems Education Journal, 3(19), 3-19.

Schulz, B. (2008). The importance of soft skills: Education beyond academic knowledge. Nawa Journal of Communication, 2(1), 146-154.

Stevenson, D. H., \& Starkweather, J. A. (2010). PM critical competency index: IT execs prefer soft skills. International Journal of Project Management, 28(7), 663-671.

Trauth, E. M., Farwell, D. W., \& Lee, D. (1993). The IS expectation gap: Industry expectations versus academic preparation. MIS Quarterly, 293-307.

Wilhelm, W. J., Logan, J., Smith, S. M., \& Szul, L. F. (2002). Meeting the demand: Teaching" soft" skills. 
Wynekoop, J. L., \& Walz, D. B. (2000). Investigating traits of top performing software developers. Information Technology \& People, 13(3), 186-195.

\section{Biography}

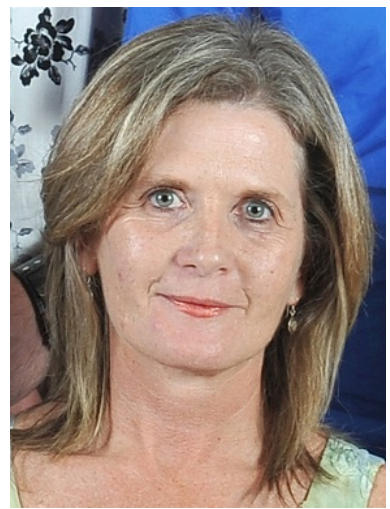

Estelle Taylor is a senior lecturer at the Potchefstroom campus of the North-West University in South-Africa. She obtained a PhD in Computer Science in 2008 from the North-West University. Her research focus is in Education of Computer Science and Information Systems. 